AKUNTABILITAS

Vol. VII No. 3, Desember 2014

P-ISSN: 1979-858X

Halaman 177 - 184

\title{
ANALISIS PEMAHAMAN WAJIB PAJAK DAN IKLAN OTORITAS PAJAK TERHADAP TINGKAT KEPATUHAN WAJIB PAJAK
}

\author{
Waluyo \\ Universitas Mercu Buana
}

\begin{abstract}
This research is casual studies conducted to establish casual relationship between variables the understanding of the taxpayer and the advertising tax againt compliance of taxpayer to pay Land and Building Tax (PBB) in the Tax Office (KPP) East Tangerang especially living in subdistrict Ciledug. Objects in this research are taxpayer who pay Land Tax in Tax Office and had seen advertising tax in both mass media and electronic media. In the technique of data analysts, this research do the validity test by pearson correlation, reliability testing with coeffiicient cronbach's alpha, the classical assumption test, hypothesis testing multiple regression, $t$ test, and $F$ test. On testing the hypothesis can be seen that the understanding of taxpayer have a significant effect on compliance of taxpayer and the advertising tax doesn't have a significant effect on compliance of taxpayer, meanwhile the understanding of taxpayer and tax advertising simultaneously had a significant effect on compliance of taxpayer.
\end{abstract}

Keywords: The Understanding of Taxpayer, Advertising, Tax Compliance of Taxpayers.

ABSTRAK: Penelitian ini merupakan penelitian kasual yang dilakukan untuk membangun hubungan kasual antara variabel pemahaman wajib pajak dan pajak iklan terhadap kepatuhan wajib pajak untuk membayar Pajak Bumi dan Bangunan (PBB) di Kantor Pelayanan Pajak (KPP) Timur Tangerang terutama yang tinggal di Kecamatan Ciledug. Objek dalam penelitian ini adalah wajib pajak yang membayar Pajak Bumi di Kantor Pelayanan Pajak dan telah melihat iklan pajak di kedua media massa dan media elektronik. Dalam teknik analis data, penelitian ini melakukan uji validitas dengan korelasi pearson, uji reliabilitas dengan alpha cronbach coeffiicient ini, uji asumsi klasik, pengujian hipotesis regresi berganda, uji t, dan uji F. Pada pengujian hipotesis dapat dilihat bahwa pemahaman wajib pajak memiliki pengaruh yang signifikan pada kepatuhan wajib pajak dan pajak iklan tidak memiliki pengaruh yang signifikan pada kepatuhan wajib pajak, sedangkan pemahaman wajib pajak dan iklan pajak secara bersamaan memiliki pengaruh yang signifikan pada kepatuhan wajib pajak.

Kata kunci: Pemahaman Wajib Pajak, Advertising, Kepatuhan Pajak Wajib Pajak

\footnotetext{
$1 *$ Draft pertama: 15 Agustus 2014 ; Revisi: 18 September 2014 ; Diterima: 1o Oktober 2014

* Penulis dapat dikontak melalui:
} 


\section{PENDAHULUAN}

Pajak merupakan salah satu penerimaan negara yang digunakan untuk membangun negara ini. Pendapatan negara yang berasal dari penerimaan pajak sangatlah signifikan jika dibandingkan dengan penerimaan dari segi lainnya. PBB merupakan pajak pusat yang dipungut oleh negara, namun pada tahun 2013 PBB untuk pedesaan dan perkotaan menjadi pajak daerah yang berarti pemungutan pajak tersebut dilaksanakan oleh masing-masing daerah sesuai dengan undang-undang Pajak Daerah dan Retribusi Daerah (PDRB). Penerimaan PBB di Indonesia dari tahun ke tahun selalu bertambah, hal ini disebabkan karena harga tanah yang cenderung naik dan semakin banyaknya bangunan sehingga penerimaan PBB menjadi lebih tinggi. Karena itu berarti pendapatan daerah akan bertambah tetapi menjadi berbanding terbalik dengan apa yang dirasakan oleh masyarakat yang membayar PBB. Semakin tinggi wajib pajak membayar PBB maka beban individu wajib pajak menjadi tinggi. Wajib pajak cenderung menginginkan beban pajak yang rendah dalam membayar pajak. Seperti pada pengertian pajak, pada hakekatnya pajak tersebut sebatgai suatu kewajiban setiap warga negara atau wajib pajak untuk memenuhinya. Pemungutannya bersifat memaksa sesuai Ketentuan Perundang-undangan Perpajakan. Pembayaran pajak sebagai bentuk desentralisasi semangat gotong- royong atau solidaritas nasional membangun Perkenomian Nasional. Kesadaran dan kepedulian sukarela Wajib Pajak sangat sulit untuk diwujudkan. Kesadaran masyarakat membayar pajak masih belum mencapai tingkat sebagaimana yang diharapkan. Umumnya masyarakat masih kurang sadar terhadap kewajiban membayar pajak. Ketidakpahaman masyarakat tentang pajak menjadi penghambat terciptanya kepatuhan pajak.

Disisi lain, iklan adalah sarana untuk penyampaian pesan dan menjadi salah satu cara bagi perusahaan atau lembaga untuk berkomunikasi dengan masyarakat luas. iklan merupakan suatu proses komunikasi yang mempunyai kekuatan sangat penting sebagai alat pemasaran yang membantu menjual barang, memberikan layanan, serta gagasan atau ide melalui saluran tertentu dalam bentuk informasi yang persuasif. Jadi secara prinsip iklan adalah bentuk penyajian pesan yang dilakukan oleh komunikator secara non personal melalui media untuk ditunjukkan kepada komunikan dengan cara membayar. Kebutuhan instansi-instansi Pemerintah terhadap media semakin meningkat terutama dalam hal pemberian informasi kepada masyarakat melalui iklan layanan masyarakat. Iklan tersebut tidak memuat pesan bisnis melainkan menyajikan pesan-pesan sosial yang dimaksudkan untuk membangkitkan kepedulian masyarakat terhadap sejumlah masalah yang dihadapi. Otoritas pajak menggunakan iklan pajak sebagai media komunikasi.

Demikian halnya pengetahuan perpajakan yang dimiliki oleh wajib pajak merupakan hal yang paling mendasar yang harus dimiliki oleh wajib pajak karena tanpa pengetahuan tentang pajak, maka sulit bagi wajib pajak dalam menjalankan kewajiban perpajakannya. Pemerintah telah melakukan upaya untuk meningkatkan pengetahuan bagi para wajib pajak, diantaranyamelalui penyuluhan, iklan-iklan di media masa maupun media elektronik dengan tujuan agar para wajib pajak lebih mudah dan lebih cepat mendapat informasi perpajakan. Informasi perpajakan tersebut tidak hanya berisi tentang kewajiban wajib pajak, namun juga terdapat penjelasan tentang pentingnya pajak bagi kehidupan berbangsa dan bernegara agar sekaligus dapat menimbulkan kesadaran wajib pajak.

Berdasarkan pemaparan di atas, peneliti tertarik menganalis pengaruh tingkat pemahaman wajib pajak terhadap tingkat kepatuhan wajib pajak dalam membayar Pajak Bumi dan Bangunan, iklan pajak berpengaruh signifikan terhadap tingkat kepatuhan wajib pajak dalam membayar Pajak Bumi dan Bangunan dan tingkat pemahaman wajib pajak dan iklan pajak secara simultan berpengaruh signifikan terhadap tingkat kepatuhan wajib pajak dalam membayar Pajak Bumi dan Bangunan. 


\section{KERANGKA TEORI DAN PENGEMBANGAN HIPOTESIS}

Pajak menurut Pasal 1 UU No.28 Tahun 2007 tentang Ketentuan Umum dan Tata Cara Perpajakan adalah kontribusi wajib kepada negara yang terutang oleh orang pribadi atau badan yang bersifat memaksa berdasarkan Undang-Undang, dengan tidak mendapat timbal balik secara langsung dan digunakan untuk keperluan negara bagi sebesar-besarnya kemakmuran rakyat. Pajak menurut Soemitro sebagaimana diberikan penjelasan oleh Waluyo (2012) bahwa pemungutan pajak sifatnya memaksa, karena pajak sebagai kewajiban yang melekat pada setiap warga Negara yang dilandasi Undang-Undang Dasar 1945 (Amandemen).

Pajak dari perspektif ekonomi dipahami sebagai beralihnya sumber daya dari sektor privat kepada sektor publik. Pemahaman ini memberikan gambaran bahwa adanya pajak menyebabkan dua situasi menjadi berubah. Pertama, berkurangnya kemampuan individu dalam menguasai sumber daya untuk kepentingan penguasaan barang dan jasa. Kedua, bertambahnya kemampuan keuangan negara dalam penyediaan barang dan jasa publik yang merupakan kebutuhan masyarakat. Sementara pemahaman pajak dari perspektif hukum merupakan suatu perikatan yang timbul karena adanya Undang-Undang yang menyebabkan timbulnya kewajiban warga negara untuk menyetorkan sejumlah penghasilan tertentu kepada negara, negara mempunyai kekuatan untuk memaksa dan uang pajak tersebut harus dipergunakan untuk penyelenggaraan pemerintahan. Merujuk pada dasar hokum yang digunakan dalam memungut Pajak Bumi dan Bangunan (PBB) yaitu Undang-undang No.28 Tahun 2009 tentang Pajak Daerah dan Retribusi Daerah yang menkhususkan untuk pemungutan PBB Pedesaan dan PBB perkotaan sangatlah delematis dalam pemungutan PBB karena bersinggungan dengan segala lapisan masyarakat yang beban pajaknya ditujukan pada pemajakan atas kepemilikkan harta baik berupa tanah dan bangunan. Terkesan tidaklah mudah membebani masyarakat wajib pajak dengan pajak. Tetapi setidaknya seperti yang dikemukakan oleh Waluyo (2012) bahwa pemungutan pajak harus mengedepankan unsure keadilan yang dikehendaki dengan keadilan vertical dan keadilan horizontal.

\section{Pemahaman Wajib Pajak}

Pemahaman menurut Porwadarminta (1991) merupakan proses berpikir dan belajar. Dikatakandemikian karena untuk menuju ke arah pemahaman perlu diikuti denganbelajar dan berpikir. Pemahaman merupakan proses, perbuatan dan cara memahami. Sedangkan arti pemahaman menurut Purwanto (1997) adalah tingkatan kemampuan yang mengharapkanseseorang mampu memahami arti atau konsep, situasi serta fakta yangdiketahuinya.

\section{Iklan Otoritas Pajak}

Menurut Kotler (Ronald, 2009) iklan adalah segala macam bentuk penyajian dan promosi ide, barang atau jasa non-personal yang dibayar oleh sponsor tertentu. Sedangkan menurut American Marketing Association(Moriarty, 2009) iklan adalah suatu cara untuk mempresentasikan barang dan jasa serta ide-ide non-personal yang dibayar dan memiliki sponsor yang jelas dan teridentifikasi. Masyarakat periklanan Indonesia (Morisan, 2010) menyatakan bahwa iklan adalah suatu bentuk pesan tentang sesuatu yang disampaikan lewat media dan ditujukan kepada sebagian atau seluruh masyarakat. Dengan demikian bentuk-bentuk iklas walaupun pihak yang melakukan pemasangan iklan dan diberikan istilah iklan otoritas pajak. Karena iklan otoritas pajak terdapat pesan kepada masyarakat umumnya. Secara umum iklan otoritas pajak adalah suatu bentuk komunikasi berupa informasi mengenai pajak yang biasanya dibayarkan melalui media yang ditujukan kepada masyarakat dengan tujuan agar masyarakat termotivasi membayar pajak. Adapun fungsi 
iklan yang disampaikan oleh Restasy (2010) bahwa iklan berfungsi sebagai sumber informasi dalam kegiatan ekonomi. Dengan iklan membantu terciptanya skala ekonomi yang lebih besar.

\section{Kepatuhan Wajib Pajak}

Kepatuhan wajib pajak sebagaimana disampaikan Devanto (2006) adalah suatu keadaan dimana wajib pajak memenuhi kewajiban perpajakan dan melaksanakan hak perpajakannya berdasarkan Undang-Undang. Sedangkan menurut Gunadi (2006) menyatakan bahwa kepatuhan wajib pajak adalah bahwa wajib pajak sudah sesuai dengan aturan-aturan yang berlaku tanpa perlu diadakannya pemeriksaan, investigasi seksama, peringatan ataupun ancaman dan penerapan sanksi hukum maupun administrasi. Kepatuhan wajib pajak dapat berbentuk kepatuhan formal dan kepatuhan informal. Kepatuhan formal adalah suatu keadaan dimana wajib pajak memenuhi kewajiban secara formal sesuai dengan ketentuan Undang-Undang perpajakan, sebagai contoh dalam hal penyampaian Surat Pemberitahuan (SPT) atau penyampaian SPOP. Sedangkan kepatuhan informal (material) adalah suatu keadaan dimana wajib pajak secara substantif atau hakikatnya memenuhi semua ketentuan material perpajakan yakni sesuai dengan isi Undang-Undang perpajakan, sebagai contoh wajib pajak PBB telah melunasi utang pajaknya sesuai dengan utang pajak yang tertuang dalam SPPT.

\section{Perumusan Hipotesis} hipotesis:

Dengan memperhatikan dan mendasarkan pada landasan teori, dapat terbentuk

$\mathbf{H a}_{\mathbf{1}}$ : Tingkat pemahaman wajib pajak berpengaruh signifikan terhadap tingkat kepatuhan wajib pajak dalam membayar Pajak Bumi dan Bangunan.

$\mathbf{H a}_{2}$ : Iklan pajak berpengaruh signifikan terhadap tingkat kepatuhan wajib pajak dalam membayar Pajak Bumi dan Bangunan.

Haz: Tingkat pemahaman wajib pajak dan iklan pajak secara simultan berpengaruh signifikan terhadap tingkat kepatuhan wajib pajak dalam membayar Pajak Bumi dan Bangunan.

\section{METODE PENELITIAN}

Objek penelitian dalam penelitian ini adalah wajib pajak yang membayar Pajak Bumi dan Bangunan (PBB) dengan unit penelitian Kantor Pelayanan Pajak (KPP) Pratama Tangerang Timur. Dalam penelitian menempatkan Kantor Pelayanan Pajak Tangerang, karena pada saat diteliti, pengelolaan Pajak Bumi dan Bangunan belum dialihkan pengelolaannya khusus Pajak Bumi dan Bangunan Pedesaan dan Perkotaan ke Pemerintah Daerah. Dalam penelitian ini digunakan dua variabel untuk mengukurnya yaitu tingkat pemahaman wajib pajak dan iklan otoritas pajak. Penelitian ini menggunakan kuesioner yang ditujukan kepada wajib pajak yang telah membayar PBB di KPP Pratama Tangerang Timur.

\section{Definisi Operasional Variabel}

Dalam penelitian ini menggunakan 2 (dua) variabel independen yaitu tingkat pemahaman Wajib Pajak (X1) dan Iklan Otoritas Pajak (X2). Sedangkan untuk variabel dependen dalam penelitian yaitu tingkat kepatuhan wajib pajak dalam membayar Pajak Bumi dan Bangunan (PBB). Variabel tingkat pemahaman wajib pajak (Xı) adalah pemahaman wajib pajak akan fungsi dan pentingnya membayar PBB yang sudah ditetapkan oleh pemerintah. Indikator untuk variabel ini adalah pemahaman wajib pajak mengenai 
PBB, prosedur pembayaran PBB, dan sanksi dalam PBB. Pengukuran variabel ini menggunakan skala likert dengan skor antara 1 sampai 5 .

Variabel iklan otoritas pajak (X2) mengukur keefektifan sebuah iklan yang dipasang otoritas pajak yang ada dalam media massa dan media elektronik. Indikator untuk variabel ini adalah isi dari iklan otoritas pajak tersebut dan frekuensi tayang atau munculnya iklan otoritas pajak. Pengukuran variabel ini menggunakan skala likert dengan skor antara 1 sampai 5. Variabel tingkat kepatuhan wajib pajak dalam membayar Pajak Bumi dan Bangunan sebagai variabel dependen. Indikator untuk variabel ini adalah wajib pajak membayar PBB secara tepat waktu, tepat jumlah, dan kesediaan wajib pajak untuk membayar sanksi.Pengukuran variabel ini menggunakan skala likert dengan skor antara 1 sampai 5. Data yang digunakan dalam penelitian ini adalah data primer. Data primer digunakan dalam mengukur semua variabel dalam penelitian. Penelitian ini menggunakan teknik non-probability sampling yang berarti tidak semua sampel mendapatkan kesempatan yang sama untuk dipilih. Metode yang digunakan dalam non-probability sampling adalah convenience, yaitu sampel dipilih berdasarkan kemudahan untuk memperolehnya. Sampel dalam penelitian ini adalah wajib pajak untuk Pajak Bumi dan Bangunan yang terdaftar di Kantor Pelayanan Pajak Tangerang Timur.

\section{HASIL DAN PEMBAHASAN}

Dari hasil uji validitas atas ketiga variabel diperoleh hasil valid dan uji realibilitasnya disimpulkan bahwa instrumen penelitian handal atau reliable. Demikian halnya dengan pengujian hipotesis dengan menggunakan regresi linier berganda dengan persamaan regresi:

Keterangan:

$$
\mathrm{KWP}=\alpha_{0}+\alpha_{1} P W P+\alpha_{2} I P+e
$$

$$
\begin{array}{ll}
\text { KWP } & =\text { Kepatuhan Wajib Pajak Dalam Membayar PBB } \\
\text { PWP } & =\text { Pemahaman Wajib Pajak } \\
\text { IP } & =\text { Iklan Pajak } \\
\alpha_{0}-\alpha_{2} & =\text { Konstanta regresi } \\
\mathrm{e} & =\text { Error }
\end{array}
$$

Uji parsial yaitu pengujian yang digunakan untuk mengetahui seberapa besar pengaruh satu variabel penjelas atau independen secara individual dalam menjelaskan variasi variabel (Ghozali, 2011). Dengan ini statistik t mempunyai nilai signifikansi $\alpha=5 \%$. Kriteria pengujian hipotesis dengan menggunakan uji statistik $\mathrm{F}$ yaitu jikai nilai signifikansi

\begin{tabular}{|c|c|c|c|c|c|}
\hline \multirow[b]{2}{*}{ Model } & \multicolumn{2}{|c|}{$\begin{array}{c}\text { Unstandardized } \\
\text { Coefficients }\end{array}$} & \multirow{2}{*}{$\begin{array}{c}\text { Standardized } \\
\text { Coefficients } \\
\text { Beta }\end{array}$} & \multirow[b]{2}{*}{$\mathrm{T}$} & \multirow[b]{2}{*}{ Sig. } \\
\hline & B & Std. Error & & & \\
\hline 1 (Constant) & 9,590 & 2,619 & & 3,662 & , ooo \\
\hline $\mathrm{X}_{1}$ & ,372 & , o76 & ,467 & 4,899 & , ooo \\
\hline $\mathrm{X}_{2}$ & , 028 & , o75 & , 035 &, 368 & ,714 \\
\hline
\end{tabular}
$\mathrm{t}(p-$ value $)<0,05$, maka hipotesis diterima sehingga variabel independen secara parsial mempengaruhi variabel dependen. Hasil uji statistik t dan uji statistik F (uji signifikansi simultan) nampak berikut ini:

Tabel 1 Hasil Uji Statistik t Coefficients $^{\mathrm{a}}$

a. Dependent Variable: Y 


\section{Uji Hipotesis}

Tingkat pemahaman Wajib Pajak berpengaruh signifikan terhadap tingkat kepatuhan Wajib Pajak dalam membayar Pajak Bumi dan Bangunan.

Berdasarakan tabel hasil uji statistik $t$ diperoleh koefisien regresi sebesar 0,467 untuk variabel kepatuhan wajib pajak yang diwakili oleh pemahaman wajib pajak. Oleh karena itu, setiap kenaikan pemahaman wajib pajak sebesar $1 \%$ akan menyebabkan peningkatan kepatuhan wajib pajak sebesar o,4679 atau 46,7\%.

Hasil dari uji t untuk variabel pemahaman wajib pajak didapatkan nilai t sebesar 4,899 dan significant sebesar o,ooo. Dari hasil tersebut, karena o,ooo < 0,05 maka dapat disimpulkan bahwa pemahaman wajib pajak memiliki pengaruh yang signifikan terhadap kepatuhan wajib pajak.

Iklan pajak berpengaruh signifikan terhadap tingkat kepatuhan wajib pajak dalam membayar Pajak Bumi dan Bangunan.

Sementara itu untuk iklan otoritas pajak (X2) diperoleh koefisien regresi sebesar o,035 untuk variabel kepatuhan wajib pajak yang diwakili oleh iklan pajak. Oleh karena itu, setiap kenaikan iklan pajak sebesar $1 \%$ akan menyebabkan peningkatan kepatuhan wajib pajak sebesar 0,035 atau 3,5\%. Untuk uji parsial antara iklan pajak (X2) dengan kepatuhan wajib pajak dapat dilihat pada nilai significant. Hasil dari uji t untuk variabel iklan pajak didapatkan nilai t sebesar 0,368 dan significant sebesar 0,714. Dari hasil tersebut, karena 0,714 > 0,05 maka dapat disimpulkan bahwa iklan pajak tidak memiliki pengaruh yang signifikan terhadap kepatuhan wajib pajak (Haz berhasil untuk ditolak).

Tingkat pemahaman wajib pajak, dan iklan pajak secara simultan berpengaruh signifikan terhadap tingkat kepatuhan wajib pajak dalam membayar Pajak Bumi dan Bangunan.

Hasil uji statistik F besarnya adjusted $R$ Square adalah o,215 atau sebesar 21,5\%. Hal ini berarti 21,5\% variasi kepatuhan wajib pajak dalam membayar PBB dapat dijelaskan oleh pemahaman wajib pajak dan iklan pajak, serta sisanya $78,5 \%$ dijelaskan oleh variabelvariabel lainnya yang tidak terdapat dalam penelitian ini. Untuk uji F didapatkan hasil nilai F sebesar 14,532 dengan tingkat signifikansi o,ooo. Hal ini menunjukkan bahwa nilai signifikansi $\mathrm{F}$ lebih kecil dari 0,05, maka dapat disimpulkan berarti bahwa pemahaman wajib pajak dan iklan pajak secara simultan memiliki pengaruh signifikan terhadap kepatuhan wajib pajak.

\section{SIMPULAN}

Berdasarkan hasil yang diperoleh dan analisis yang dilakukan mengenai pemahaman wajib pajak dn iklan otoritas pajak dapat ditarik kesimpulan bahwa pemahaman wajib pajak berpengaruh signifikan terhadap kepatuhan wajib pajak dalam membayar Pajak Bumi dan Bangunan (PBB). Hal ini dibuktikan dari nilai significant yang bernilai lebih kecil dari o,05. Pengetahuan tentang pajak khususnya Pajak Bumi dan Bangunan mempunyai peran penting dalam meningkatkan kepatuhan Wajib Pajak dalam membayar Pajak Bumi dan Bangunan. Dengan pemahaman Wajib Pajak yang memadai dapat menumbuhkan motivasi Wajib Pajak berlaku patuh dalam memenuhi kewajiban pajaknya. Khusus Pajak Bumi dan Bangunan menuntut pemahaman pajak dalam bingkai kewajiban setiap warga Negara dalam memenuhi kewajiban membayar pajak.

Iklan otoritas pajak tidak berpengaruh signifikan terhadap kepatuhan wajib pajak dalam membayar Pajak Bumi dan Bangunan (PBB). Hal ini dibuktikan dari nilai significant yang bernilai lebih besar dari 0,05. Komunikasi antara otoritas pajak dengan Wajib Pajak dalam perkembangannya menggunakan berbagai media cetak maupun media elektronik. 
Namun, tidak setiap Wajib Pajak mengetahui atau memahami makna dan pesan yang akan disampaikan Otoritas Pajak. Kemungkinan karena unsur keterbatasan atau karakteristik responden sehingga menghasilkan pengaruh yang berbeda.

Pemahaman wajib pajak dan iklan otoritas pajak secara simultan berpengaruh signifikan terhadap kepatuhan wajib pajak dalam membayar Pajak Bumi dan Bangunan (PBB). Hal ini dibuktikan dari nilai significant yang bernilai lebih kecil dari o,05. Dari hasil uji secara simultan menghasilkan bahwa pemahaman Wajib Pajak dan iklan pajak berpengaruh terhadap kepatuhan. Walaupun variabel iklan otoritas pajak secara parsial tidak berpengaruh.

\section{PUSTAKA ACUAN}

Budi, Ikhsan. 2007. Kajian Terhadap Faktor-Faktor yang Mempengaruhi Kepatuhan Wajib Pajak. Jurnal Akuntansi, Manajemen Bisnis dan Publik (JAMBSP) Vol. 3 No. 3 Juni 2007.

Blech, George dan Michael Blech. 2009. Advertising and Promotion Edition 8. McGraw-Hill International Edition.

Ghani, Achmad. 2009. Analisis Faktor-Faktor yang mempengaruhi Kinerja Pegawai Kantor Pelayanan Pajak Bumi dan Bangunan Kota Makasar. Jurnal Aplikasi Manajemen Vol. 7 No. 1 Februari 2009.

Ghozali, Imam. 2009. Aplikasi Analisis Multivariate Dengan Program SPSS. Semarang : Badan Penerbit Universitas Diponegoro.

Ghozali, Imam. 2011. Aplikasi Analisis Multivariate Dengan Program SPSS. Semarang: Badan Penerbit Universitas Diponegoro.

Hassan, Dahliana. 2008. Pelaksanaan Tax Compliance Dalam Upaya Optimalisasi Penerimaan Pajak di Kota Yogyakarta. Mimbar Hukum Vol. 20 No. 2 Juni 2008.

Moriaty, Mitchell dan Wells. 2009. Advertising Principle and practice edition 8. Pearson. Morisan. Periklanan Komunikasi Pemasaran Terpadu. Jakarta: Kencana. 2010.

Nawangsasi, Restu. 2010. Pengaruh Persepsi Wajib Pajak atas Pelayanan Publik, Iklan Pajak dan Kesadaran Wajib Pajak Terhadap Kepatuhan Wajib Pajak. Jurnal FE (Akuntansi) UI Vol. 6 No. 6 Tahun 2010.

Ngalim, Purwanto. 1997. Prinsip-Prinsip dan Teknik Evaluasi Pengajaran. Bandung: PT. RemajaRosdakarya.

Pranawa. 2008. Ketetapan Pajak, Surat Tagihan Pajak Sebagai Pendorong Kepatuhan Wajib Pajak. Jurnal Akuntansi dan Pajak Vol. 3 No. 5 Tahun 2008.

Purwono, Herry. 2010. Dasar-Dasar Perpajakan \& Akuntansi Pajak. Jakarta: Erlangga.

Resmi, Siti. 2008. Perpajakan :Teori dan Kasus Edisi 4. Jakarta: Salemba Empat.

Restaty, Niken. 2010. Modul Pengantar Periklanan. Jakarta: Pusat Pengembangan Bahan Ajar UMB.

Ronald, Karen Whitehill King dan Thomas Russel. 2009. Prosedur Periklanan. Jakarta: Indeks.

Rusjdi, Muhammad. 2005. PBB, BPHTB \& Bea Materai. Jakarta: Indeks.

Sasana, Hadi. 2005. Analisis Faktor-Faktor yang Mempengaruhi Penerimaan Pajak Bumi dan Bangunan (PBB). Dinamika Pembangunan Vol. 2 No. 1 Juli 2005.

Sekaran, Umar dan Roger Bougie. 2009. Research Methods for Business. Wiley.

Shimp, Terence. 2010. Integrated Marketing Communication in Advertising and Promotion. South-Western, Cengage Learning.

Sholichah, Mu'minatus dan Istiqomah. 2005. Perilaku Wajib Pajak Terhadap Tingkat Keberhasilan Penerimaan Pajak Bumi dan Bangunan di Kabupaten Gresik. Jurnal Logos Vol. 3 No. 1 Juli 2005.

Suandy, Erly. 2006. Perpajakan Edisi 2. Jakarta: Salemba Empat. 
Sutianingsih. 2008. Pengaruh Kesadaran, Pelayanan, dan Pendidikan Terhadap Kepatuhan Wajib Pajak. Jurnal Akuntansi dan Pajak Vol. 8 No. 16 Tahun 2008.

Thoyib, M. 2008. Analisis Variabel-Variabel yang Mempengaruhi Penerimaan Pajak Bumi dan Bangunan di Kota Palembang. Ilmiah Volume I No. 1 Tahu 2008.

Waluyo. 2012. Perpajakan Indonesia. Jakarta: Salemba Empat.

W.J.S., Porwadarminta. 1991. Kamus Besar Bahasa Indonesia. Jakarta: Balai Pustaka.

\section{Ketentuan Perundang-Undangan}

Direktorat Jenderal Pajak. 1994. Undang-Undang Nomor 12 Tahun 1994 tentang Pajak Bumi dan Bangunan (PBB).

Direktorat Jenderal Pajak. 2007. Undang-Undang Nomor 28 Tahun 2007 tentang Ketentuan Umum dan Tata Cara Perpajakan. 